\title{
Cloning and Expression of Serotype-2 Simian Betaretrovirus Reverse Transcriptase Gene Isolated from Indonesian Cynomolgus Monkey in Escherichia coli
}

\author{
UUS SAEPULOH ${ }^{1}$, DIAH ISKANDRIATI ${ }^{1}$, FUNGKEY HOETAMA ${ }^{2}$, SELA SEPTIMA MARIYA ${ }^{1}$, \\ DEDY DURYADI SOLIHIN ${ }^{3}$, JOKO PAMUNGKAS ${ }^{1,4}$, AND DONDIN SAJUTHI $^{1,4}$
}

\author{
${ }^{\prime}$ Primate Research Center, Institut Pertanian Bogor (PSSP LPPM IPB), Jalan Lodaya II/5, Bogor 16151, Indonesia; \\ ${ }^{2}$ Faculty of Biotechnology, Unika Atma Jaya, Jalan Jenderal Sudirman 51, Jakarta 12930, Indonesia; \\ ${ }^{3}$ Department of Biology, Faculty of Mathematics and Natural Science, Institut Pertanian Bogor, \\ Kampus Darmaga, Bogor 16680, Indonesia; \\ ${ }^{4}$ Faculty of Veterinary Medicine, Institut Pertanian Bogor, Kampus Darmaga, Bogor 16680, Indonesia
}

In this study, we isolated simian betaretrovirus serotype-2 (SRV-2) reverse transcriptase (RT) gene from infected Indonesian cynomolgus monkey (Macaca fascicularis). The gene was then cloned in Escherichia coli expression system. The SRV-2 RT gene is located between nucleotides 3284-4925 in the polyprotein $(\mathrm{Pol})$ region encodes 547 amino acids. Analysis of expression using SDS-PAGE and western blot techniques showed a specific band of $64.9 \mathrm{kDa}$, indicating SRV-2 RT recombinant enzyme. Purification of SRV-2 RT recombinant

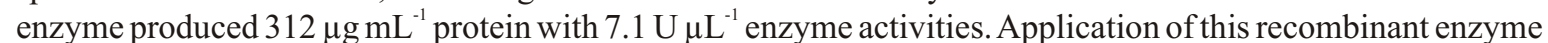
in reverse transcription-PCR (RT-PCR) of $\beta$-globin and $\beta$-actin genes produced DNA fragments of 206 and 350 $\mathrm{bp}$, indicating amplification of $\beta$-globin and $\beta$-actin genes, respectively. Therefore, the expressed SRV-2 RT enzyme was proven to be functional, although the activity was low.

Key words: Escherichia coli expression system, recombinant enzyme, reverse transcriptase, SRV-2

Pada penelitian ini, dilakukan isolasi gen reverse transcriptase (RT) simian betaretrovirus serotipe-2 (SRV2) yang menginfeksi monyet ekor panjang (Macaca fascicularis) asal Indonesia. Gen tersebut selanjutnya diklonakan ke dalam sistem ekspresi Escherichia coli. Gen RT SRV-2 berada pada posisi nukleotida 3284-4925 di daerah polyprotein ( $\mathrm{Pol}$ ) yang mengkodekan 547 asam amino. Analisis hasil ekspresi menggunakan teknik SDS-PAGE dan western blot menunjukkan adanya pita protein spesifik berukuran 64,9 kDa yang diperkirakan sebagai enzim rekombinan RT SRV-2. Pemurnian enzim rekombinan RT SRV-2 menghasilkan $312 \mu \mathrm{g} \mathrm{mL}$

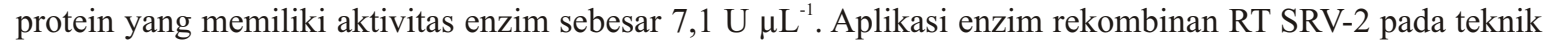
reverse transcription-PCR (RT-PCR) terhadap target gen $\beta$-globin dan $\beta$-aktin menghasilkan pita DNA berukuran 206 dan $350 \mathrm{pb}$. Dengan demikian, enzim rekombinan RT SRV-2 terbukti berfungsi memiliki aktivitas enzim walaupun aktivitasnya masih rendah.

Kata kunci: enzim rekombinan, reverse transcriptase, sistem ekspresi Escherichia coli , SRV-2

Reverse transcription is an essential and critical step in the life cycle of all retroviruses replication (Telesnitsky and Goff 1997; Sarafianos et al. 2009). Reverse transcriptase (RT) is a multifunctional enzyme that catalyzes the formation of doublestranded deoxyribonucleic acid (DNA) from singlestranded ribonucleic acid (RNA) viral genomes (Telesnitsky and Goff 1997; Hizi and Herschhorn 2008). This enzyme is responsible for genome replication of viruses possessing RNA- and DNA polymerase and RNase $\mathrm{H}$ activities (Hizi and Herschhorn 2008). RT has become an important enzyme in molecular biology, genetics and medicine for the synthesis of complementary DNA (cDNA) from messenger RNA (mRNA) (Telesnitsky and Goff

*Corresponding author; Phone: +62-251-8320417, Fax. +62251-8360712,E-mail: uussaepuloh@yahoo.com
1997; Herschhorn and Hizi 2010). The application of this enzyme combining with PCR amplification technique (RT-PCR) has expanded our knowledge of numerous cellular regulatory mechanisms and has become a gold standard to facilitate the coding region of any gene of interest. The development of biotechnology has been relying on the availability of this efficient RTs (Herschhorn and Hizi 2010). Until nowadays, the reverse transcriptases of human immunodeficiency virus type-1 (HIV-1) and Moloney murine leukemia virus (MMLV) have been extensively characterized. The RT of HIV-1, the virus causing acquired immunodeficiency syndrome (AIDS), is a prime target for the development of antiretroviral drug therapy of HIV-1/AIDS and the most studied enzyme in biomedical research (Kohlstaedt et al.1992). Meanwhile, the MMLV-RT is the most widely used 
enzyme for cDNA synthesis and RNA amplification due to its robust catalytic activity and high fidelity (Kotewitcz et al.1988; Taube et al. 1998).

Simian betaretroviruses (SRVs) are the causative agents of simian acquired immunodeficiency syndrome (SAIDS) in Asian macaques with varying severity (Marx et al. 1984; Gardner et al. 1988; Lerche 2010). Regarding potentially active infection and immune abnormality affected by this virus, SRVs is a pathogenic agent that should be eliminated in the Macaca breeding colony (Marx et al. 1984; Morton et al. 2008). This SRVs infection poses some problems for breeders providing a population of SRV-free macaques, since macaques are frequently used as animal model in biomedical researches (Lerche and Osborn 2003). While SRV is an important pathogen in Asian macaques and causes a potential confounding variable in biomedical research, SRV also provides a valuable viral model to compare with other retrovirals for a better understanding of aspects of retroviral-host interactions, infection mechanism, retroviral structure, antiretroviral, and vaccine development (Montiel et al, 2010; Lerche and Osborn 2003). Recently, SRV-2 have been isolated and characterized from wild Indonesian Macaca fascicularis of which the sequence analysis of envelope region showed 96\% homology to SRV-2 (Iskandriati et al. 2010). The SRVs' genome contains three major genes, 5'-gag-pol-env-3'. Each gene plays a role in the production of viral proteins (Marracci et al. 1995; Marracci et al. 1999). The RT sequence is located within the pol coding domain of this retrovirus. The gene encoding RT can be isolated and cloned to produce RT recombinant enzyme.

In this study, we report the expression of SRV-2 RT gene isolated from Indonesian $M$. fascicularis in Escherichia coli, its purification, and its enzymatic activity measurement of the gene product.

\section{MATERIALS AND METHODS}

\section{Isolation of SRV-2 RT Gene Using PCR} Technique. DNA was extracted from PBMCs (peripheral blood mononuclear cells ) of Indonesian $M$. fascicularis infected SRV-2 (archived sample of PSSP LPPM IPB) using QIAmp Blood DNA Minikit (Qiagen, Hilden, Germany). The SRV-2 RT gene was amplified using specific primers SRV-2: RT3284U (5'CACCCCTGTTTGGGTTGATC-3') and SRV-2 RT4925R (5'-CTAGTGATTACCTTGAGATAAAGG TCC-3'). The forward primer was designed with the addition of CACC nucleotides that would facilitate the cloning of the gene into the pENTR/SD/TOPO entry vector. Meanwhile, reverse complement of stop codon UAG (CTA) was added to the reverse primer for correct expression in N-terminal fusion pDEST17 vector. PCR amplification was performed using $P f x$ DNA polymerase of Thermococcus sp that has low error rate and proof reading activity. Additional primers for sequencing were M13F (5' -TGTAAAACGACGGCCA GT-3'), M13R (5'-GGTCATAGCTGTTTCCTG-3'), SRV-2 RT 3751R (5'-GCCCAAGATTTTCTGATTGG -3'), SRV-2 RT 3799F (5'-GATTGGCGAACAAGTTT TGC-3'), SRV-2 RT 4247F (5'-TACTGGCCTCTTCTG G-3'), and SRV-2 RT 4604F (5'-GGCATAGCCGCATA CACTTT-3'). These primers were developed using Primer3 program (http://primer3.wi.mit.edu/) based on SRV-2 complete genome (GenbankAF126467.1).

SRV-2 RT Gene Cloning and Expression. SRV-2 RT gene was inserted to pENTR/SD/TOPO according to procedure from Invitrogen, USA and transformed to E.coli TOP10. Transformants were selected on LB agar plate containing $50 \mu \mathrm{g} \mathrm{mL}^{-1}$ kanamycin antibiotic. The clone was then cultured in LB broth and incubated at 37 ${ }^{\circ} \mathrm{C}$ for $18 \mathrm{~h}$. Plasmid was extracted using QIAprep Spin Miniprep kit (Qiagen, Hilden, Germany), then analyzed by PCR and sequencing techniques using M13 universal primer to prove the gene target was inserted correctly. SRV-2 RT gene in $\mathrm{pENTR/SD/TOPO}$ (Invitrogen, California, USA) was then sub-cloned to pDEST17 (Invitrogen, California, USA) destination vector between nucleotide positions 147 and 1830, downstream of $6 \times$ His-tag gene and transformed to $E$. coli $\mathrm{DH} 5 \alpha$. Analysis of recombination was performed by PCR and sequenced using T7 promotor forward primer and SRV-2 RT4925R primer. pDEST17 containing target gene was transformed to E.coli BL21AI using heat shock methods. The tranformant was then grown in $5 \mathrm{~mL}$ LB broth containing $100 \mu \mathrm{g}$ $\mathrm{mL}^{-1}$ ampicillin until the $\mathrm{OD}_{600}$ was $0.6-1.0$. The culture was used to inoculate fresh LB medium containing 100 $\mu \mathrm{g} \mathrm{mL} \mathrm{L}^{-1}$ ampicillin, which was then let to grow until mid-log phase $\left(\mathrm{OD}_{600}\right.$ of $\left.\sim 0.4\right)$ prior to induction with 20\% L-Arabinose.

Purification and Expression Analysis of SRV-2 RT Recombinant Enzyme. E. coli BL21AI expressing SRV-2 RT recombinant protein was cultured overnight in $1 \mathrm{~L}$ of LB broth and then centrifuged at $10000 \times \mathrm{g}$ for $10 \mathrm{~min}$. Pelleted cells were lyzed using native binding buffer containing $50 \mathrm{mM}$ potassium phosphate $\mathrm{pH} 7.8,400 \mathrm{mM} \mathrm{NaCl}, 100 \mathrm{mM}$ $\mathrm{KCl}, 10 \%$ glycerol, $0.5 \%$ Triton $\mathrm{X} 100$, and $10 \mathrm{mM}$ imidazole, and added with $8 \mathrm{mg}$ lysozyme. The affinity 
chromatography with $\mathrm{Ni}^{2+}$-NTA chelating agent was used for further purification (Qiagen, Hilden, Germany). Recombinant enzyme concentration was determined using Bicinchoninic Acid (BCA) assay (Thermo Scientific, Illinois, USA). Expression of SRV-2 RT recombinant enzyme was detected by SDSPAGE. Meanwhile, western blot was performed to analyze the serological reaction using antibody against $6 \times$ Histidine-tag (Invitrogen, California, USA) to SRV2 RT.

SRV-2 RT Recombinant Enzyme Activity Analysis. SRV-2 RT enzyme was determined quantitatively using RT chemiluminescent assay (Roche, Penzberg, Germany) based on the ability of RT enzyme to synthesize new DNA from template/primer hybrid poly $(\mathrm{A}) \times$ oligo $(\mathrm{dT})_{15}$. Assay was conducted in reaction mixture containing $46 \mathrm{mM}$ Tris- $\mathrm{HCl}, 266 \mathrm{mM}$ potassium phosphate, $27.5 \mathrm{mM}$ magnesium chloride, $9.2 \mathrm{mMDDT}, 10 \mathrm{mM}$ dUTP/dTTP, and template/primer hybrid, at final $\mathrm{pH}$ of 7.8. The reaction mixture was incubated for $1 \mathrm{~h}$ at $37{ }^{\circ} \mathrm{C}$. The amount of this synthesized DNA is used as a parameter of RT enzyme activity following a sandwich ELISA (enzyme-linked immunosorbent assay) protocol. Digoxigenin- and biotin-labeled nucleotides in an optimized ratio are incorporated into the same DNA molecule, which is newly synthesized by the RT. Biotin-labeled DNA binds to the surface of microplate that have been precoated with streptavidin. An antibody to digoxigenin, conjugated to horseradish peroxidase (anti-DIG-POD), binds to the digoxigenin-labeled DNA. The chemiluminescent peroxidase substrate luminol/4iodophenol is added. Peroxidase in the presence of hydrogen peroxide $\left(\mathrm{H}_{2} \mathrm{O}_{2}\right)$ catalyzes the oxidation of luminol, resulting in reaction products that quantified using ELISA reader at the absorbance $490 \mathrm{~nm}$ that directly correlated to the level of RT activity in the sample. The specific activity of DNA polymerase were expressed in Unit (U) that means as the amount of enzyme required for the incorporation of $1 \mathrm{nmol}$ of labeled dNTP in $10 \mathrm{~min}$ at $37{ }^{\circ} \mathrm{C}$ using poly (A) $\times$ oligo $(\mathrm{dT})_{15}$ as template/primer hybrid.

Meanwhile, this SRV-2 RT rombinant enzyme was applied to reverse transcription-PCR (RT-PCR) technique to qualitatively analyze the enzyme's ability in reverse transcribing the RNA template to the cDNA. The methods was referred to Superscript III reverse transcriptase (Invitrogen, California, USA) and the cDNA PCR amplification was performed to amplify $\beta$-globin and $\beta$-actin as housekeeping genes.

\section{RESULTS}

SRV-2 RT Gene Isolation and Cloning. In this study, reverse transcriptase gene was isolated from SRV-2 pol located at positions 3284-4925 specific band of about $1600 \mathrm{bp}$ was shown in gel electrophoresis (Fig 1), indicating the presence of the targeted gene. PCR analysis using M13 forward and reverse primers was performed to verify the SRV-2 RT in $\mathrm{pENTR} / \mathrm{SD} / \mathrm{TOPO}$ plasmid, resulted the specific amplicon of about $2000 \mathrm{bp}$ (Fig 2). The nucleotides sequence analysis was analyzed by BLAST program (http://blast.ncbi.nlm.nih.gov/), indicating the presence of the gene target, with $99 \%$ (1631 of 1641 nucleotides) similarities to SRV-2 RT D2/RHE/OR isolate (Genbank AF126467.1). The gene of interest was inserted to the vector in correct direction without any nucleotide shifts nor mutations in the reading frame. The insertion site was downstream of the ribosome binding site (RBS) and flanked by att $\mathrm{L} 1$ and $a t t \mathrm{~L} 2$. It was proven that the target gene had been successfully inserted in the plasmid (Fig 3).

SRV-2 RT Recombination into pDEST17 E. coli Expression System. The SRV-2 RT cloned in pENTR/SD/TOPO entry plasmid had been subcloned to $\mathrm{pDEST} 17$ destination vector by LR recombination reaction. pDEST17 is a vector, which is $\mathrm{N}$-terminally fused with $6 \times$ His tags for purification purposes. ATG initiation codon lies upstream of the $6 \times$ His tags. Analysis of recombination in the pDEST17 vector by PCR amplification using the T7 promoter primer to SRV-2 RT 4925R produced a specific fragment of of about 1800 bp (Fig 4). Nucleotide sequence analysis indicated that the SRV-2 RT gene had been inserted properly, in frame within the vector.

SRV-2 RT Enzyme Expression Analysis. SDSPAGE analysis of SRV-2 RT recombinant protein showed the presence of a band at molecular weight approximately $64.9 \mathrm{kDa}$ (Fig 5). This result was confirmed by molecular weight calculation of 547 amino acids SRV-2 RT and six histidines, using the software from website http://www.expasy.org/compute pi/Mw. SRV-2 RT recombinant protein has been successfully purified using $\mathrm{Ni}^{2+}$-NTA spin column affinity chromatography. The purified expressed protein was eluted using imidazole, which binds nickle ion more tightly than 6xHis. In this research, purification method was performed under native conditions that the $6 \times$ His-SRV-2 RT enzymes was in soluble condition. However, under this condition, the non-tagged proteins will also interact with $\mathrm{Ni}^{2+}$-NTA 


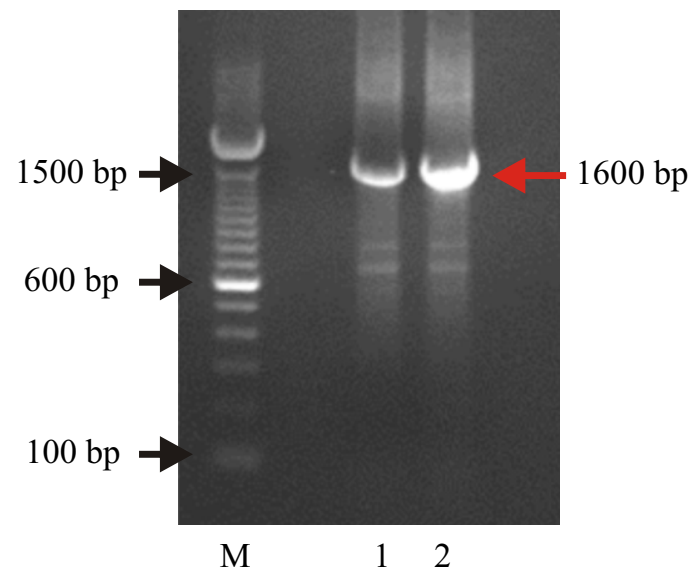

Fig 1 SRV-2 RT gene amplification using specific primer SRV-2 RT 3284F and 4925R. M: 100 bp DNA ladder (Invitrogen); 12: 1600 bp PCR product of SRV-2 RT.

A

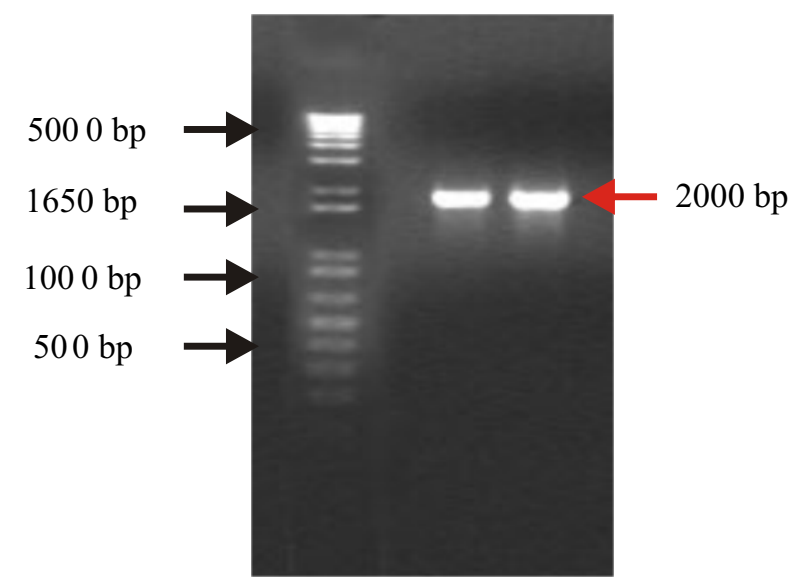

B

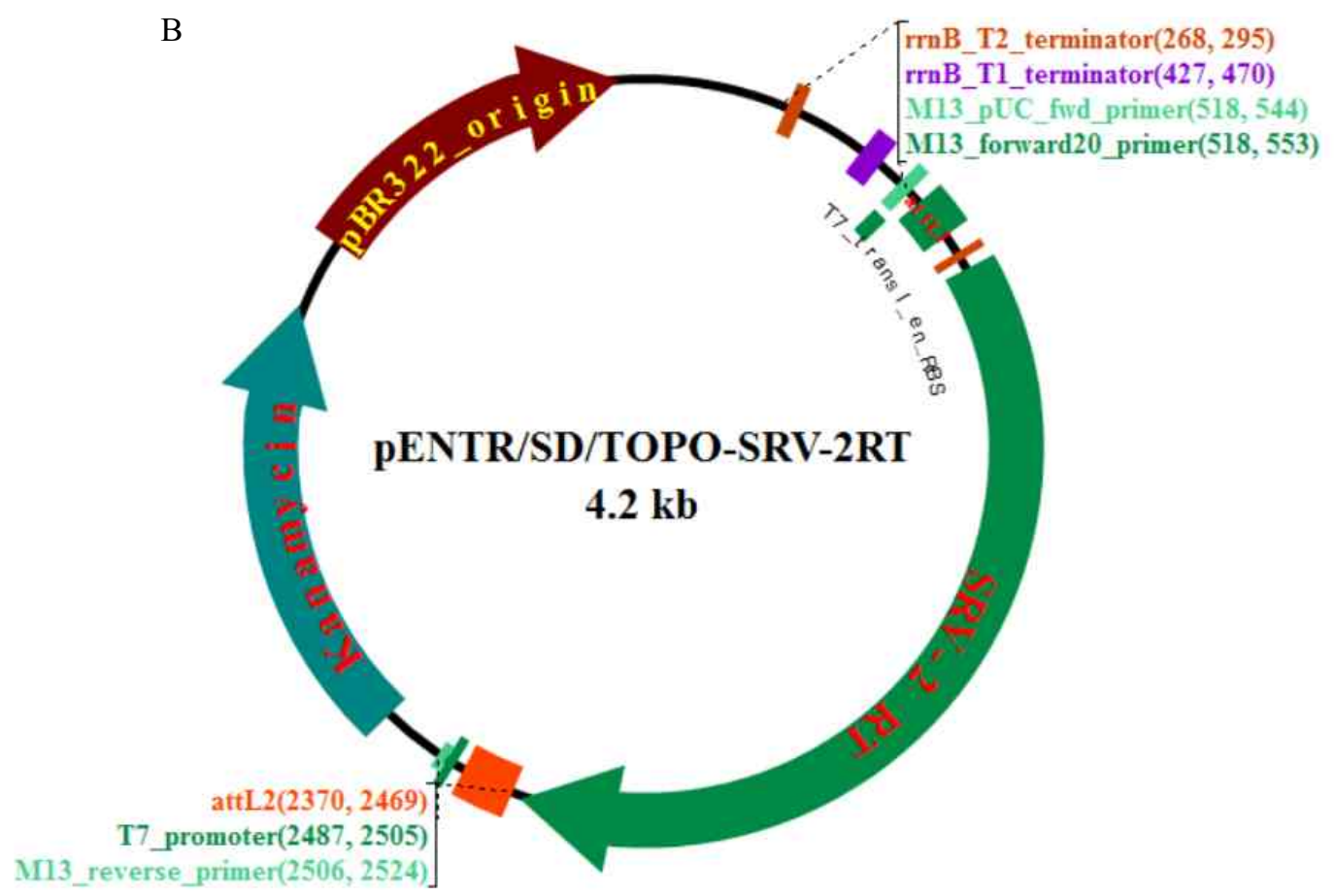

Fig 2 (A) PCR amplification to pENTR/SD/TOPO SRV-2 RT plasmids using M13 F and M13 R primer. M: 1kb DNA ladder (Invitrogen); 1-2: $2000 \mathrm{bp}$ amplicon contained SRV-2 RT gene. (B) Genetic map illustration of pENTR/SD/TOPO-SRV2 RT vector. 
M13 Forward primer TGTAAAACGACGGCCAGTCTTAAGCTCGGGCCCCAAATAATGATTTTATTTTGACTGATAGTGACCTGTTCGTTGCA att $\mathrm{L} 1$ ACAAATTGATGAGCAATGCTTTTTTATAATGCCAACTTTGTACAAAAAAGCAGGCTCCGCGGCCGCCTTGTTTAACT RBS SRV-2 RT3284F SRV-2 RT gene

TTAAGAAGGAGCCCTTCACCCCTGTTTGGGTTGATCAATGGCCCCTAACTCAAGAAAAACTTGCTGCTGCCCAACAGT TAGTGCAAGAACAATTACAGGCAGGGCATATTATAGAAAGTAATTCTCCCTGGAATACACCTATATTTGTCATAAAAA AGAAGTCTGGTAAATGGAGGCTTTTGCAAGATTTAAGGGCGGTAAATGCCACCATGGTATTAATGGGAGCTCTCCAAC CTGGGCTGCCCTCACCAGTGGCTATTCCTCAGGGATATTTTAAAATAGTCATTGATCTTAAAGATTGTTTTTTTACTA TCCCCCTTCAGCCCGTTGATCAAAAGCGATTTGCTTTTAGTCTCCCGTCTACCAACTTTAAACAACCAATAAAACGTT ATCAATGGAAAGTGTTGCCTCAAGGCATGGCCAATAGTCCTACCTTGTGTCAAAAATATGTAGCTGCTGCTATAGAGC CAATCAGAAAATCTTGGGCACAAATGTACATTATACACTATATGGATGACATTCTAATAGCAGGAAAGATTGGCGAAC AAGTTTTGCAGTGTTTTGCTCAACTTAAACAAGCATTGACAACTACTGGGTTACAAATAGCTCCAGAAAAGGTACAGC TACAAGATCCATATACCTACCTTGGGTTTCAACTTAATGGTCCCAAAATTACCAATCATAAGGCAGTTATTCGTAGAG ATAAGTTACAAACCCTTAATGATTTTCAAAAACTTTTGGGAGATATCAATTGGCTTAGACCCTATTTACACCTCACTA CAGGAGATCTAAAACCTCTTTTTGATATCCTAAAAGGGGATTCTAATCCTAACTCACCCAGATTTTTATCTGAAGCAG CCCTTACGTCTCTTAAAAAGGTAGAAACAGCTATTGCTGAACAATTTGTTACACAAATAGATTATACACAGCCATTGA ССTTTTTAATTTTTAATACTACACTGACACCTACTGGCCTCTTCTGGCAAAATAATCCTGTCATGTGGGTTCACTTGC CTGCATCGCCAAAAAAGGTATTGTTCCCCTATTATGATGCTATAGCAGATCTTATTATCCTTGGAAGGGACAACAGTA AAAAATATTTTGGACTTGAACCATCTACTATTATACAACCCTATTCTAAATCTCAAATCCATTGGTTAATGCAAAACA CAGAAACATGGCCAATTGCCTGCGCTTCCTATGCAGGCAACATTGATAATCATTATCCACCCAATAAACTTATTCAAT TTTGCAAACTCCATGCAGTTGTTTTTCCCCGAATCATTAGTAAAACTCCTCTAGACAATGCCTTACTGGTATTCACTG ATGGATCCTCTACCGGCATAGCCGCATACACTTTTGAAAAGACCACTGTCAAATTTAAAACCTCCCATACGTCAGCCC AATTAGTAGAATTACAAGCCCTAATTGCAGTGTTATCGGCCTTTCCTCATCGGGCCCTCAATATTTATACAGATAGTG CATACTTAGCTCATTCTATACCTCTACTTGAGACAGTATCGCAAATCAAACATATCTCAGACACAGCAAAATTATTTT TACAGTGCCAACAACTAATATGCAACAGGTCTATACCCTTTTATTTAGGACATATCAGGGCCCATTCAGGATTACCAG GACCTTTATCTCAAGGTAATCACTAGAAGGGTGGGCGCGCCGACCCAGCTTTCTTGTACAAAGTTGGCATTATAAGAA SRV-2 RT4925R AGCATTGCTTATCAATTTTTGCAACGAACAGGTCACTATCAGTCAAAATAAAATCATTATTTGCCATCCAGCTGATA attL2 TCCCCTATAGTGAGTCGTATTACATGGTCATAGCTGTTTCCTG M13 reverse primer

Fig 3 Nucleotide sequences of Indonesian isolate's SRV-2 RT at nucleotide positions 3284-4925 inserted in the $\mathrm{pENTR/SD/TOPO} \mathrm{vector.} \mathrm{Nucleotide} \mathrm{sequences} \mathrm{of} \mathrm{vector} \mathrm{and} \mathrm{SRV-2} \mathrm{RT} \mathrm{gene} \mathrm{were} \mathrm{highlighted} \mathrm{in} \mathrm{yellow} \mathrm{and} \mathrm{grey,}$ respectively. Primer positions were indicated with red letters.

resin at higher affinity than in denaturating condition. This was shown by the large number of proteins appearing in the binding buffer (Fig 5A). The result of the BCA assay showed that protein concentration was $2280 \mu \mathrm{g} \mathrm{mL}^{-1}$. This non-specific binding could have been reduced by adding low concentration of imidazole in the washing buffers. The concentration of purified RT-SRV-2 eluted with acidic buffer containing high concentration $(250 \mathrm{mM})$ of imidazole was $306 \mu \mathrm{g}$ $\mathrm{mL}^{-1}$ protein (Table 1). For further expression analysis, Western blot was performed using anti-6xHis-tag antibody showed the presence of a specific band around $64.9 \mathrm{kDa}$ (Fig 5B).

Analysis of SRV-2 RT Recombinant Enzyme Activities. Purified SRV-2 RT recombinant enzyme had the activity of 1420 Unit in $200 \mu \mathrm{L}$ elution buffer, therefore, the enzyme volumetric activity was $7.1 \mathrm{U}$ $\mu \mathrm{L}^{-1}$ and the enzyme specific activity was $22.76 \mathrm{U} \mathrm{mg}^{-1}$ total protein (Table 1). The purified SRV-2 RT recombinant enzyme ( $3 \mu \mathrm{L}$ of $21 \mathrm{U}$ is the optimum reaction) was then applied in RT-PCR, to create in comparison to $1 \mu \mathrm{L}$ of $200 \mathrm{U}$ commercial MMLV-RT from Invitrogen, cDNA of $\beta$-globin and $\beta$-actin using Hela cell as mRNA template (Invitrogen). The PCR produced $206 \mathrm{bp}$ and $350 \mathrm{bp}$ fragments corresponding to $\beta$-globin and $\beta$-actin, respectively (Fig 6). The result proved the functionality of the expressed SRV-2 RT.

\section{DISCUSSIONS}

SRV-2 RT gene was cloned in $\mathrm{pENTR/SD/TOPO}$ entry vector before being subcloned by site specific recombination into $\mathrm{pDEST} / 17$ destination E.coli expression system. The recombination was mediated by LR Clonase II enzyme mix, a mixture of the bacteriophage $\lambda$ integrase (Int) and excisionase (Xis), and the E. coli integration host factor (IHF) protein (Shuman 1994; Landy 1989; Hunt 2005). This vector was designed to facilitate high-level, inducible expression of recombinant proteins in E. coli using the pET system. The system takes advantage of the high activity and specificity of the bacteriophage T7 RNA polymerase to allow regulated expression of heterologous genes in E. coli from the T7 promoter 
A

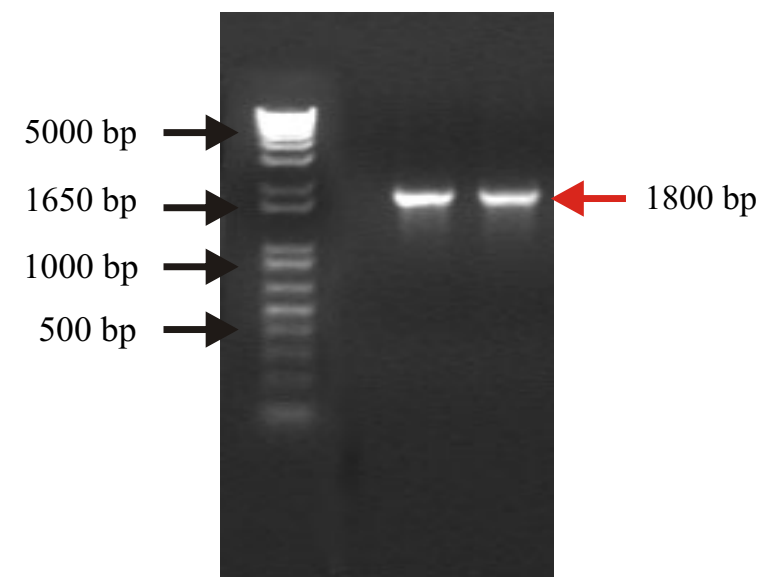

B

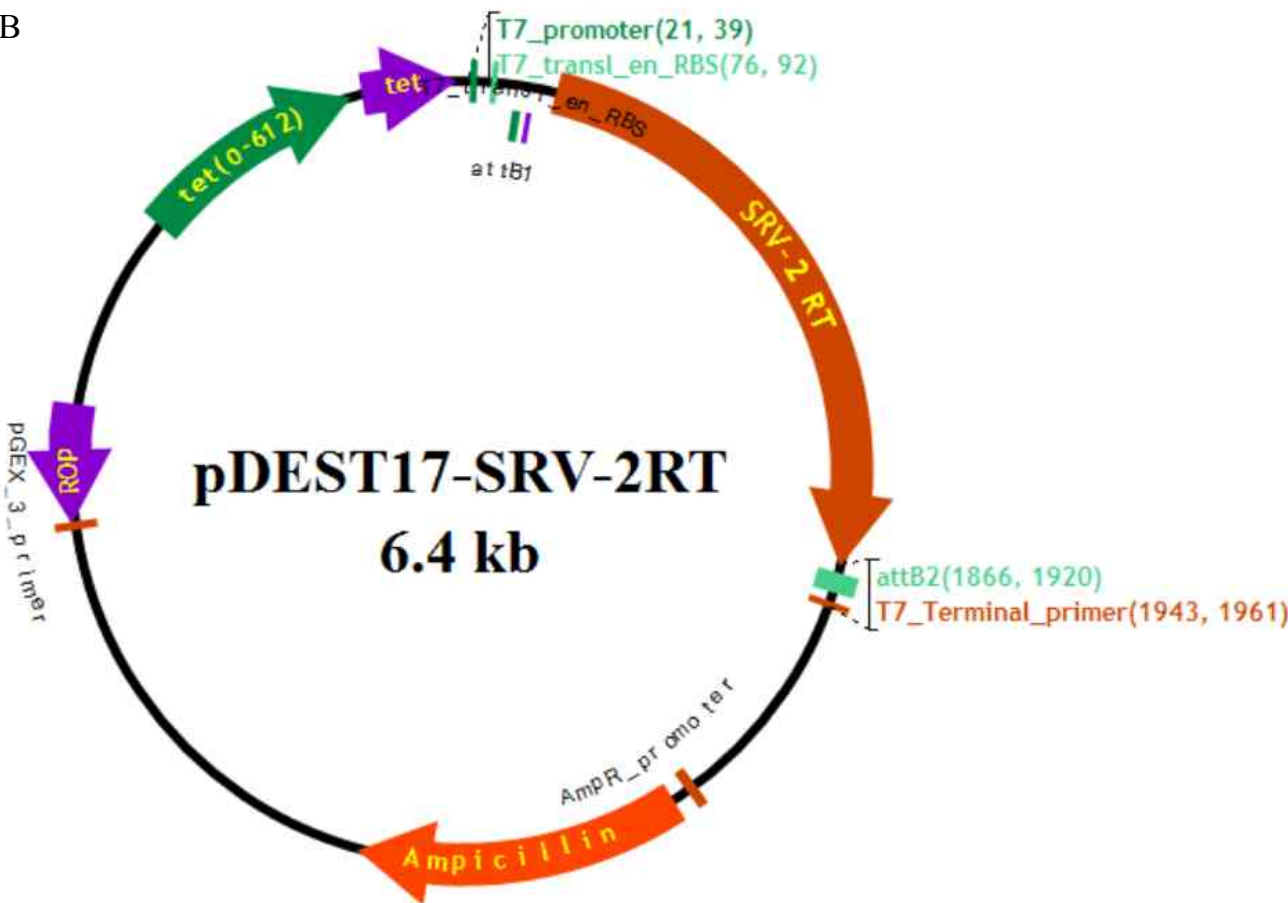

Fig 4 (A) PCR amplification to pDEST17 SRV-2 RT plasmids using T7 forward primer and SRV-2 RT4148 reverse primer. M: $1 \mathrm{~kb}$ DNA ladder (Invitrogen); 1-2: 1800 bp amplicon containing SRV-2 RT gene. (B) Genetic map illustration of $\mathrm{pENTR/SD/TOPO-SRV-2} \mathrm{RT} \mathrm{vector.}$

(Rosenberg et al. 1987).

SDS-PAGE and western blot analyses indicated that the molecular weight of our SRV-2 RT $6 \times$ His Nterminal fusion protein was $64.9 \mathrm{kDa}$. The $6 \times \mathrm{His}$ tag is small enough that it does not affect the structure and functionality of the expressed protein. In addition the tag allows the protein to be purified under denaturing and native conditions, which is useful if refolding of insoluble proteins is to be attempted. However, Nterminal $6 \times$ His tags does not only plays a role in protein recombinant purification but also seems to have stabilizing effect on the mRNA structure in the translation initiation region (Svensson et al. 2006).
Comparison of $\mathrm{N}$ - versus $\mathrm{C}$-terminal positioning of His tag on several proteins expressed in bacteria and eukaryotes as well as analyses of the protein expression level and solubility indicated that, in most cases, the Nterminal tags improved protein expression (Busso et al. 2003; Svensson et al. 2006). However, in this study we had only the soluble active SRV-2 RT enzyme, while any attempts to recover enzymatically active preparation of the insoluble inclusion bodies had been unsuccessful. In the case of the Gateway expression vector pDEST-17, the $\mathrm{N}$-terminal $6 \times$ His tag is followed by an additional 21 amino acids that arise from transcription through the Gateway recombination and topoisomerase sites. 

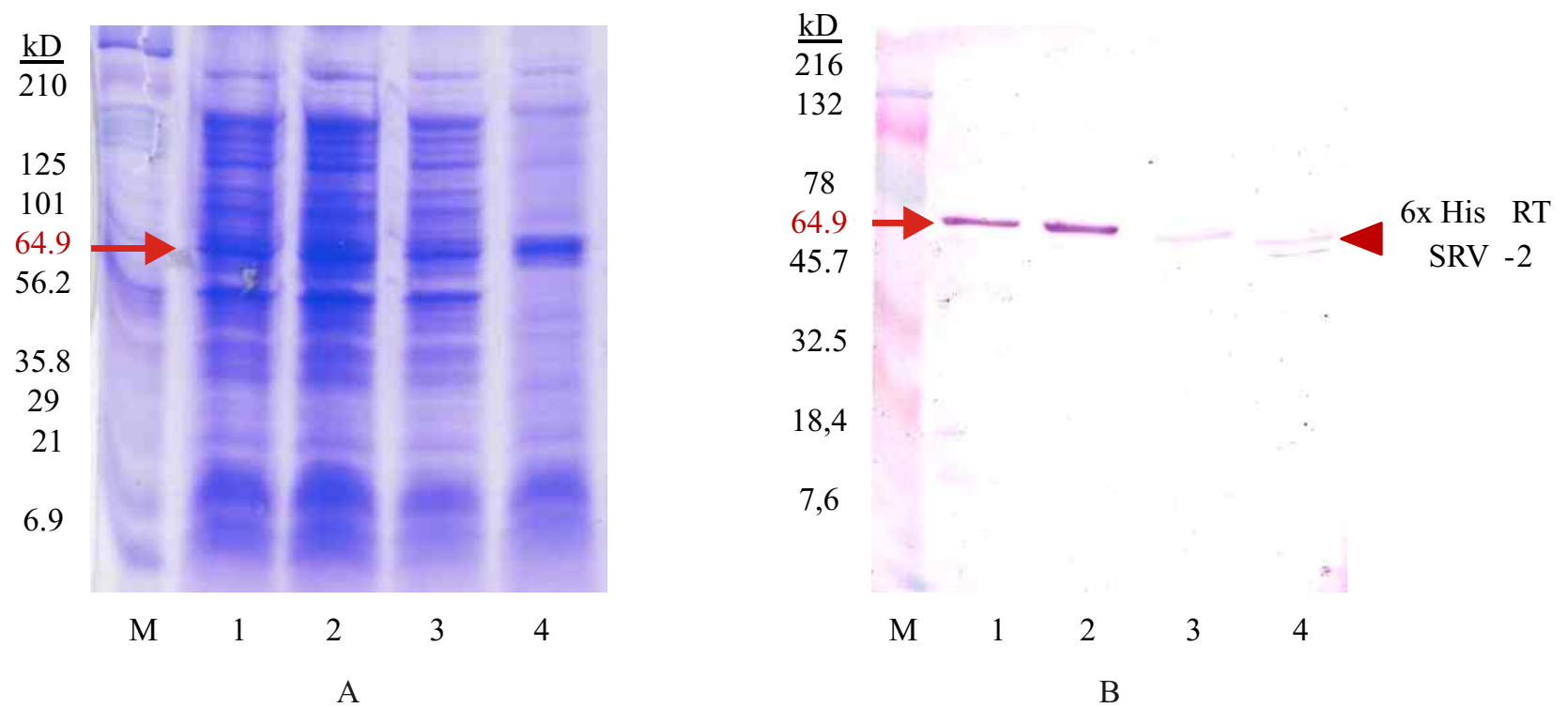

Fig 5 SRV-2 RT recombinant enzyme expression analysis of pre- and post- $\mathrm{Ni}^{2+}$-NTA purification produced specific band at $64.9 \mathrm{kDa}$. (A) 10\% SDS PAGE stained with Coomassie brilliant blue. M: Broad range prestained protein marker (BioRad); 1: pre-purified, 2: binding buffer, 3: washing buffer, 4: elution buffer. (B) Western blot analysis using HRP conjugated anti-polypeptide Histidine antibody. M: Kaleidoskop ${ }^{\mathrm{TM}}$ prestained protein marker (BioRad); 1: pre-purified; 2: elution buffer; 3: washing buffer; 4: binding buffer.

Table 1 Protein concentration and activities of the $\mathrm{Ni}^{2+}$-NTA purified RT SRV-2

\begin{tabular}{|c|c|c|c|c|c|}
\hline $\begin{array}{c}\text { Fraction of } \\
\text { Purification Step }\end{array}$ & $\begin{array}{c}\text { Protein } \\
\text { Concentration } \\
\left(\mu \mathrm{g} \mathrm{mL}^{-1}\right)\end{array}$ & $\begin{array}{l}\text { Total } \\
\text { Protein } \\
\text { (mg) }\end{array}$ & $\begin{array}{c}\text { Enzyme } \\
\text { Concentration } \\
\left(\mathrm{U} \mu \mathrm{L}^{-1}\right)\end{array}$ & $\begin{array}{c}\text { Total } \\
\text { Enzyme } \\
\text { Activity (U) }\end{array}$ & $\begin{array}{c}\text { Enzyme } \\
\text { Specific } \\
\text { Activity } \\
\text { (U mg } \mathrm{m}^{-1} \text { protein) }\end{array}$ \\
\hline Pre-purified & 2760 & 1656 & 0.10 & 60 & 0.04 \\
\hline Binding buffer & 2280 & 1368 & 0.15 & 90 & 0.07 \\
\hline Washing buffer & 578 & 346.8 & 0.24 & 144 & 0.42 \\
\hline Elution buffer & 312 & 62.4 & 7.1 & 1420 & 22.76 \\
\hline
\end{tabular}

The protein concentration was determined by Pierce BCA Protein Assay Kit (Thermo Scientific) and the enzyme activity was measured by Reverse Transcriptase Assay chemiluminescent Kit (Roche).

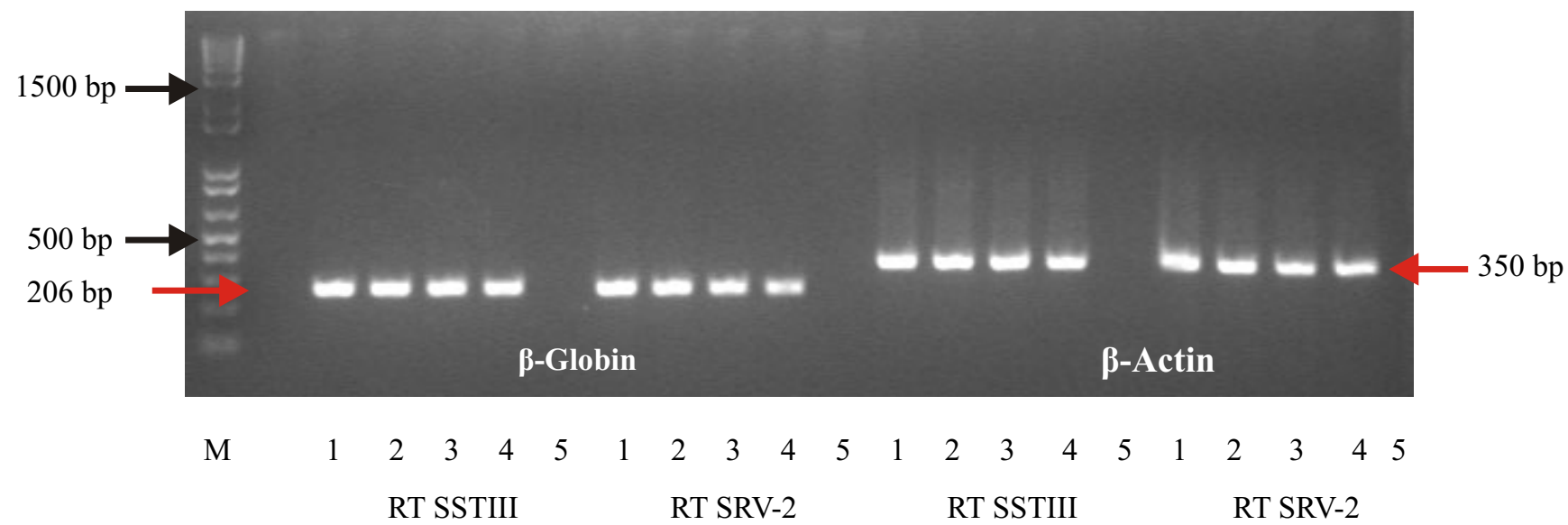

Fig 6 Comparison of two steps RT PCR products of $\beta$-globin and $\beta$-actin house keeping genes using SRV-2 RT enzyme and SSIII RT commercial enzyme (Invitrogen). The PCR produced $206 \mathrm{bp}$ and $350 \mathrm{bp}$ bands representing the $\beta$-globin and $\beta$-actin, respectively. 1: 100 bp DNA ladder(Invitrogen); 1-4: repeated samples; 5: master mix control. 
Although we did not remove the additional amino acids, we were quite certain that the properties of the recombinant SRV-2 RT are similar, if not identical, to those of the native RT enzyme. Western blot analysis of this soluble N-terminal $6 \times$ His SRV-2 RT using anti-6× His antibody indicated the presence of a specific band of $64.9 \mathrm{kDa}$, confirming the presence of the tagged protein.

Three dimensional protein modelling demonstrated that, like other RTs, SRV-2 was a multi-functional enzyme possessing the RNA-dependent DNA polymerase (RDDP), DNA-dependent DNA polymerase (DDDP), and RNase H activities (Saepuloh, submitted for publication). In this study, we only analyzed quantitatively the RDDP catalytic activities based on oligo $(\mathrm{dT})_{15}$ primers elongation on poly(rA)n templates (Table 1). As already found for most RTs, among the synthetic template-primers suitable for the RDDP activity, poly (rA) $n$ (oligo(dT) $)_{12-18}$ is the most efficient (Taube et al. 1998). Divalent cations are required for the catalytic activities of most DNA polymerases, including the SRV-2 RT, which used $\mathrm{Mg}^{2+}$ as an enzyme cofactor. SRV-2 RT enzyme activity was also measured qualitatively by using the enzyme in a two-step reverse transcription PCR. The ability of this enzyme in reverse transcribing mRNA template into cDNA followed by PCR amplification using a pair specific primer designed for coding sequences gene, indicated that this SRV-2 RT has the RDDP and DDDP activities.

The volumetric activity of the purified SRV-2 RT recombinant enzyme was $7.1 \mathrm{U}_{\mu} \mathrm{L}^{-1}$. The activity was lower compared to the commercial enzymes, for examples theMMLV RT Superscript III (Invitrogen) and avian myoblastosis virus (AMV) RT (Promega, Wisconsin, USA), of which the activities were $200 \mathrm{U}$ $\mu \mathrm{L}^{-1}$ and $20-25 \mathrm{U} \mu \mathrm{L}^{-1}$, respectively. It is possible that the one step $\mathrm{Ni}^{2+}$-NTA chromatography was not enough to remove protein contaminants from the enzyme eluate, thus causing the low enzymatic activity. On the other hands, it is also possible that different groups of retrovirus indeed have different activities. If this is the case, then we will also have to bear in mind that the RT enzymes whose activities we were comparing came from different groups, MMLV is a gammaretrovirus, AMV is an alpharetrovirus, and SRV-2 is a betaretrovirus. It is known that although RTs from the different groups of retrovirus share similar functional catalytic activities, they differ significantly in various parameters, such as structure and subunit compositions, molecular weights, catalytic properties, biochemical and biophysical characteristics and sensitivity to different inhibitors (Herschhorn and Hizi 2010).
In conclusion, SRV-2 RT gene was successfully isolated, cloned and expressed in E. coli. The expressed protein had also been purified and successfully used in RT-PCR. Although the functionality of this recombinant SRV-2 RT enzyme was proven indeed the activity was lower than commercial enzymes. Therefore, it seems still necessary to optimize the expression of the recombinant SRV-2 RT enzyme and to concentrate the product to increase the activity. In addition, it is also necessary to characterize the biochemical and kinetic properties of the enzyme, if we intend to further study the enzyme or to use it for commercial production. This preliminary result was for us very intriguing to explore this enzyme in depth in the next study.

\section{ACKNOWLEDGMENTS}

This study was supported financially by the Directorate General of Higher Education (DIKTI), Ministry of Education and Cultural, Republic of Indonesia through IPB Competitive Grant 2012 and DIPA SEAMEOBIOTROP 2012.

\section{REFERENCES}

Busso D, Delagotte-Busso B, Moras D. 2005. Construction of a set gateway-based destination vectors for highthroughput cloning and expression screening in Escherichia coli. J Anal Biochem. 343(2):313-321. doi:10.1016/j.ab.2005.05.015.

Gardner MB, Luciw P, Lerche N, Marx P. 1988. Nonhuman primate retrovirus isolates and AIDS. Adv Vet Sci Comp Med. 32:171-190.

Herschhorn A, Hizi A. 2010. Retroviral reverse transcriptase. Cell Mol Life Sci. 67(16):2717-2747. doi:10.1007/s00018-010-0346-2.

Hizi A, Herschhorn A. 2008. Retroviral reverse transcriptases (other than those of HIV-1 and murine leukemia virus): A comparison of their molecular and biochemical properties. Virus Res. 134(1-2):203-220. doi:10.1016/j.virusres.2007.12.008.

Hunt I. 2005. From gene to protein: A review of new and enabling technologies for multi parallel protein expression. Protein Expr Purif. 40(1):1-22. doi:10.1016/j.pep.2004.10.018.

Iskandriati D, Saepuloh U, Mariya S, Grant RF, Solihin DD, Sajuthi D, Pamungkas J. 2010. Isolation and characterization of simian retrovirus type D from Macaca fascicularis and M. nemestrina in Indonesia. Microbiol Indones. 4(3):132-136. doi: 10.5454/mi.4.3.6.

Kohlstaedt LA, Wang J, Friedman JM, Rice PA, Steitz TA. 1992. Crystal structure at 3.5 A resolution of HIV-1 reverse transcriptase complexed with an inhibitor. Science 256(5065):1783-1790. doi:10.1126/science.13 77403. 
Kotewitcz M, Sampson CM, D’Alessio M, Gerard GF. 1988. Isolation of cloned moloney murine leukemia virus reverse transcriptase lacking ribonuclease $\mathrm{H}$ activity. Nucleic Acid Res. 16(1):265-277. doi:10.1093 /nar/16.1.265.

Landy, A. 1989. Dynamic, structural, and regulatory aspect of site-specific recombination. Annu Rev Biochem. 58:913-949. doi:10.1146/annurev.bi.58.070189.004405.

Lerche NW. 2010. Simian retroviruses: Infection and disease-implications for immunotoxicology research in primates. J Immunotoxicol. 7(2):93-101 . doi:10.3109/1 5476911003657406.

Lerche NW, Osborn KG. 2003. Simian retrovirus infections. Potential confounding variables in primate toxicology studies. Toxicol Pathol. 31(Suppl):103-111.

Marracci GH, Avery NA, Shiigi SM, Couch G, Palmer H, Pilcher KY, Nichols H, Hallick LM, Axthelm MK, Machida CA. 1999. Molecular cloning and cellspecific growth characterization of polymorphic variants of type D serogroup 2 simian retroviruses. Virology 261(1):43-58. doi:10.1006/viro.1999.9858.

Marracci GH, Kelley RD, Pilcher KY, Crabtree L, Shiigi SM, Avery N, Leo G, Webb MC, Hallick LM, Axthelm MK. 1995. Simian AIDS type D serogroup 2 retrovirus: isolation of an infectious molecular clone and sequence analyses of its envelope glycoprotein gene and 3' long terminal repeat. J Virol. 69(4):2621-2628.

Marx PA, Maul DH, Osborne KG. 1984. Simian AIDS: isolation of type $\mathrm{D}$ retrovirus and disease transmission. Science 223(4640):1083-1086. doi:10.1126/science.66 95196.

Montiel NA. 2010. An updated review of simian betaretrovirus (SRV) in macaque hosts. J Med Primatol.
39(5):303-314. doi:10.1111/j.1600-0684.2010.00412.x.

Morton WR, Agy MB, Capuano SV, Grant RF. 2008. Specific pathogen free macaques: definition, history and current production. ILAR J. 49(2):137-144. doi:10.1093/ilar.49.2.137.

Rosenberg AH, Lade BN, Chui DS, Lin SW, Dunn JJ, Studier FW. 1987. Vectors for selective expression of cloned DNAs by T7 RNA polymerase. Gene 56(1):125135. doi:10.1016/0378-1119(87)90165-X.

Sarafianos SG, Marchand B, Das K, Himmel D, Parniak MA, Hughes SH, Arnold E. 2009. Structure and function of HIV-1 reverse transcriptase: molecular mechanisms of polymerization and inhibition. $\mathrm{J}$ Mol Biol.385(3): 693-713. doi:10.1016/j.jmb.2008.10.071.

Shuman S. 1994. Novel approach to molecular cloning and polynucleotide synthesis using vaccinia DNA Topoisomerase. J Biol Chem. 269(51):32678-32684.

Svensson J, Andersson C, Reseland JE, Lyngstadaas P, Bulow L. 2006. Histidine tag fusions increases expression levels of active recombinant amelogenin in Escherichia coli. Protein Expr Purif. 48(1):134-141. doi:10.1016/j.pep.2006.01.005.

Taube R, Loya S, Avidan O, Perach M, Hizi A. 1998. Reverse transcriptase of mouse mammary tumour virus: expression in bacteria, purification and biochemical characterization. Biochem J. 329(3): 579587.

Telesnitsky A, Goff SP. 1997. Reverse transcriptase and the generation of retroviral DNA. In Coffin JM, Hughes SH, Varmus HE, editors. Retroviruses. New York: Cold Spring Harbor Laboratory Press. p 121-160. 